\title{
Hubungan Minat Membaca Buku-Buku IPS dengan Prestasi Belajar Siswa dalam Mata Pelajaran IPS di SDN 38/IX Jambi Kecil
}

\author{
Darmo \\ Guru SDN 38/IX Jambi Kecil
}

\begin{abstract}
Abstrak. Penelitian ini dilatar belakangi oleh gejala ketidakmauan siswa dalam menjawab pertanyaan tentang pelajaran yang diberikan, hal tersebut disebabkan oleh kurang maunya siswa untuk menghafal materi pelajaran dan berkunjung ke perpustakaan untuk membaca. Melalui penelitian ini akan diungkapkan hubungan minat membaca terhadap prestasi belajar siswa dalam mata pelajaran IPS dan pada tingkat manakah hubungan minat membaca yang paling dominan yang dirasakan siswa terhadap prestasi belajarnya dalam mata pelajaran IPS. Hubungan minat membaca yang dimaksudkan dalam penelitian ini adalah terbatas pada pengaruh, sumbangan dan manfaat dari kegemaran membaca terhadap prestasi belajar dalam mata pelajaran IPS yang dirasakan oleh siswa di sekolah, minat membaca merupakan kekuatan motivasi yang mendorong siswa untuk memusatkan perhatian pada aktivitas membaca sangat besar terhadap prestasi belajarnya, dalam mata pelajaran IPS. Maka di asumsikan siswa akan memiliki minat membaca yang besar pula. Penelitian ini diadakan di SD Negeri 38/IX Jambi Kecil terhadap 52 orang siswa kelas IV, V dan VI yang terpilih sebagai sampel penelitian yaitu 50\% dari 104 orang siswa populasi. Teknik pengumpulan data yang digunakan dalam penelitian ini adalah menggunakan angket yang terdiri dari 39 item yang diberikan langsung kepada 52 orang responden sebagai sampel penelitian. Hasil pengujian angket diadministrasikan secara kelompok dan dianalisa dengan teknik persentase. Berdasarkan hasil penelitian terungkap bahwa: Klasifikasi minat membaca buku-buku IPS siswa adala rata-rata $72,15 \%$. Dari data ini dapat diambil kesimpulan bahwa klasifikasi minat membaca yang paling dominan adalah berada pada tingkat tinggi. 1) Klasifikasi prestasi belajar siswa adalah dalam mata pelajaran IPS berada pada rata-rata 7,19 dari data ini dapat diambil kesimpulan bahwa klasifikasi prestasi belajar siswa yang paling dominan adalah berada pada tingkat tinggi. 2) Hubungan minat membaca puku-buku IPS terhadap prestasi belajar siswa dalam mata pelajaran IPS adalah sedang yaitu 0,638. Artinya korelasi sedang hubungan memadai. Kesimpulan dari hasil penelitian menunjukkan bahwa ada hubungan yang memadai antara minat membaca buku-buku IPS dengan prestasi belajar siswa dalam mata pelajaran IPS di SD Negeri No. 38/IX Jambi Kecil. Jadi kepada semua pihak yang bertanggung jawab terhadap peningkatan minat membaca siswa, khususnya siswa SD Negeri No. 38/IX Jambi Kecil hendaknya Iebih memotifasi siswa untuk meningkatkan minat membacanya. Sebab hubungan minat membaca yang dirasakan siswa terhadap prestasi belajar dalam mata pelajaran IPS akan lebih bermakna bila diikuti oleh aktivitas nyata.

Kata kunci: minat baca; IPS; prestsi belajar siswa
\end{abstract}

\begin{abstract}
This research is motivated by the symptoms of students' unwillingness to answer questions about the lessons given, it is caused by the unwillingness of students to memorize the subject matter and visit the library to read. Through this research will be revealed the relationship of interest in reading to student achievement in social studies subjects and at what level the relationship of the most dominant reading interest felt by students towards their learning achievement in social studies subjects. The relationship of reading interest that is intended in this study is limited to the influence, contribution and benefits of reading fondness towards learning achievement in social studies subjects felt by students in school, reading interest is a motivating force that encourages students to focus their attention on reading activities is very large towards learning achievement, in social studies subjects. So it is assumed students will have a great interest in reading as well. The research was conducted at 38 Negeri IX Jambi Kecil Elementary School on 52 class IV, V and VI students selected as a research sample, namely 50\% of 104 population students. Data collection techniques used in this study were using a questionnaire consisting of 39 items given directly to 52 respondents as research samples. Questionnaire test results are administered as a group and analyzed using percentage techniques. Based on the results of the study revealed that: Classification of interest in reading social studies books students is an average of $72.15 \%$. From this data it can be concluded that the classification of the most dominant reading interests is at a high level. 1) Classification of student achievement is in social studies subjects are at an average of 7.19 from this data it can be concluded that the classification of student achievement is the most dominant is at a high level. 2) The relationship of interest in reading social studies books on student achievement in social studies subjects is moderate, namely 0.638. This means that the correlation is adequate. The conclusions from the results of the study indicate that there is an adequate relationship between interest in reading social studies books and student achievement in social studies subjects at SD Negeri No. 38 / IX Small Jambi. So to all parties responsible for increasing interest in reading students, especially elementary school students No. 38 / IX Jambi Minor should motivate students to increase their interest in reading. Because the relationship of reading interest felt by students towards learning achievement in social studies subjects will be more meaningful iffollowed by real activities.
\end{abstract}

Keywords: interest in reading; Social studies; student achievement

\section{PENDAHULUAN}

Kegiatan membaca adalah tuntutan yang sangat penting bagi remaja sekolah, dengan mambaca dapat memperoleh informasi. fakta dan pengetahuan. Melalui kegiatan membaca buku-buku pelajaran, siswa dapat memahami dan menguasa materi peiajaran yang dibacanya. Oleh sebab itu kegiatan belajar tidak mungkin 
dapat dipisahkan dari aktivitas membaca. Bahkan dalam hal-hal tertentu sulit untuk membedakannya. Menurut Mulyono. Abdurrahman (1999-199) membaca merupakan salah satu komponen dari sisitem komunikasi, kemampuan membaca harus dimiliki oleh semua anak, karena melalui membaca anak dapat belajar banyak tentang berbagai bidang. Oleh karena itu membaca merupakan keterampilan yang harus diajarkan sejak anak masuk SD dan kesulitan belajar membaca harus secepatnya diatasi. Menurut Sutja dkk (1992 : 1) membaca dalam arti luas tidak hanya terbatas merangkai hurup menjadi kata, kata menjadi kalimat dan seterusnya. Akan tetapi membaca juga berusaha memahami atau enggali informasi dari apa yang dibacanya. Bahkan menurut Sukardi (2000: 98-99) salah satu aktifitas dalam belajar adalah visual activities yang termasuk didalamnya adalah menganalisa bahan/materi yang disajikan dalam bentuk wacana atau teks yang perlu dianalisa, dengan kata lain keterampilan membaca sebagai syarat utama yang harus dipenuhi. Demikian juga menurut Surya Brata (1982 : 54-56) suatu Iangkah dalam proses berfikir adalah bentuk pengertian. Salah satu tingkatan yang harus dipenuhi dalam bentuk pengertian adalah menganalisa.

Dalam menganalisa membaca merupakan syarat utama yang harus dimiliki oleh siswa terutama bila bahan pelajaran yang di sajikan dalam bentuk wacana atau bacaan. Proses belajar merupakan kegiatan mental mengolah bahan berfikir atau pengalaman yang lain. Proses belajar itu tertujuan pada sumber belajar dan bahan pelajaran yang disajikan guru. Sebagian besar bahan pelajaran itu disajikan dalam bentuk bacaan (buku sumber). Menurut Dimyati dan Mudjiono (1994 : 230) salah satu faktor internal dalam belajar adalah mengolah bahan pelajaran, seperti bagaimana membaca kamus, dan bahan pelajaran lain-lain. Kesemua aktifitas tersebut tidak dapat dipisahkan dengan aktifitas membaca. Permasalahannya saat ini adalah kegemaran membaca perang-perang Indonesia sangat rendah, termasuk siswa Sekolah Dasar dan SMP. Hal ini sesuai dengan apa yang diungkapkan oleh Chouwitan (1997 : 3) bahwa mayoritas orang-orang Indonesia termasuk anak-anak SD dan SMP jarang membaca bila tidak dipaksakan. Padahal membaca merupakan kemampuan prasyarat sekaligus faktor yang cukup mempengaruhi proses hasil belajar seseorang. Siswa yang gemar membaca diprediksikan akan memperoleh hasil prestasi belajar yang tinggi di sekolah dan sabaliknya, siswa yang kurang membaca akan memperoleh prestasi belajar yang sangat rendah. Penomena kurangnya minat membaca pada din siswa juga ditemukan di SD Negeri No. 38/IX Desa Jambi Kecil. Sebagian guru-guru yang bertugas di Sekolah tersebut mengeluh dengan kebiasaan siswa yang kurang mau membaca atau mengulangi pelajaran di rumah.

Kurangnya minat membaca siswa nampak dari gejala-gejala yang sering muncul saat proses belajar mengajar berlangsung, seperti tidak mampunya siswa dalam menjawab pertanyaan-pertanyaan tentang pelajaran yang pernah diberikan. Siswa sulit untuk mengingat karena siswa jarang mengulangi atau membaca pelajaran yang diajarkan Demikian pula halnya dengan mata pelajaran yang membutuhkan aktifitas membaca dalam memahaminya seperti pelajaran IPS dan Sejarah. Ada suatu kecendrungan tentang kebiasaan siswa yang kurang mau manghafal materi pelajaran tersebut. Siwa cendrung menyukai bahan pelajaran yang tidak banyak membutuhkan hafalan atau aktifitas membaca. Guru-guru sulit untuk menciptakan situasi pembelajaran yang menyenangkan sewaktu pelajaran IPS atau Sejarah. Siswa Iebih tertarik mendengarkan guru bercerita atau menjelaskan, sedangkan, bila siswa ditugaskan untuk mencari sendiri atau mempelajari sendiri bahan pelajaran melalui membaca buku sewaktu mengerjakan LKS, siswa sexing mengalami kegagalan atau salah dalam mengerjakannya.

Gejala yang menunjukkan kurangnya minat membaca siswa di sekolah adalah jarangnya siswa menggunakan perpustakaan sekolah sebagai salah satu sumber belajar. Siswa mau mengunjungi perpustakaan bila ada tugas dari guru, bila tidak ada tugas, maka siswa tidak mau menggunakan buku-buku yang ada di perpustakaan. Hal ini dapat dilihat dari sedikit sekali jumlah siswa berminat untuk meminjamkan buku-buku di perpustakaan sekolah.

Berdasarkan pengalaman, selama bertugas di SD Negeri No. 38.IX Jambi Kecil, siswa memang kurang berminat untuk mengulangi pelajaran di rumah. Gejala ini dapat dilihat dari hasil siswa sewaktu ulangan, jarang sekali siswa yang memperolah nilai tinggi, terutama dalam mata pelajaran IPS dan Sejarah. Berlatar belakang uraian diatas. menarik perhatian penulis untuk melakukan penelitian guna mengetahui ada tidaknya hubungan antara minat membaca buku-buku IPS dengan prestasi belajar siswa dalam mata pelajaran IPS di SD Negeri No. 38/IX Desa Jambi Kecil Kecamatan Maro Sebo Kabupaten Muaro Jambi. 


\section{METODE PENELITIAN}

Berdasarkan permasalahan dan tujuan yang akan dicapai dalarn penelitian ini, maka penelitian ini ada!ah penelitian koregasi yakni penelitian yang bertujuan untuk melihat ada tidaknya hubungan antara suatu variabel dengan variabel lainnya. Hal ini dipertegas Suharsimi Arikanto (1998:251) penelitian korelasi untuk menentukan ada tidaknya hubungan, dan apabila ada hubungan, berapa hubungannya serta berarti atau tidak hubungan itu. Sejalan dengan itu A.Muri Yusuf (1990:71) menyatakan bahwa penelitian korelasi adalah untuk menentukan hubungan antara variabel satu dengan variabel Iainnya, sehingga memeperoleh data yang akurat tentang hubungan itu. Jadi penelitian hubungan (korelasi) adalah penelitian dengan tuiLar untuk memperoleh gambaran tentang hubungan antara dua variable atau lebih. Dalam penelitian ini yang akan dihubungkan adalah minat membaca dengan hasil belajar siswa SD Negeri: 38/IX Jambi Kecil. Hasil yang diharapkan hanya merupakan gambaran dari minat membaca dengan hasil belajar siswa kelas IV (empat) sampai kelas VI (enam) Sekolah Dasar Negeri Nomor: 38/IX Jambi Kecil, dan tidak dapat berlaku pada tempat lain, artinya gambaran itu hanya terbatas pada sekolah tersebut.

\section{HASIL PENELITIAN DAN PEMBAHASAN \\ Deskripsi Data}

Berikut ini akan dipaparkan hasil pengolahan data tentang minat membaca siswa yang diperoleh melalui 39 item angket yang disebarkan kepada 52 orang responden, sebagai sampel penelitian yang diolah dengan teknik persentase sebagaimana yang disajikan pada tabel di bawah ini :

Tabel 1. Deskripsi Data

\begin{tabular}{ccccccc}
\hline No & Kode Responden & & Ya & Jumlah & Tidak & $\begin{array}{c}\text { Total } \\
\text { Ya + Tidak }\end{array}$ \\
\hline 1 & & & 3 & 5 & 6 & 7 \\
1 & 1,4 & 34 & 87,18 & 5 & 12,82 & 39 \\
2 & 2,4 & 33 & 84,62 & 6 & 15,38 & 39 \\
3 & 3,4 & 32 & 82,05 & 7 & 17,95 & 39 \\
4 & 4,4 & 27 & 69,23 & 12 & 30,77 & 39 \\
5 & 5,4 & 26 & 66,67 & 13 & 33,33 & 39 \\
6 & 6,4 & 28 & 71,79 & 11 & 28,21 & 39 \\
7 & 7,4 & 36 & 92,31 & 3 & 77,69 & 39 \\
8 & 8,4 & 27 & 69,23 & 12 & 30,77 & 39 \\
9 & 9,4 & 21 & 53,85 & 18 & 46,25 & 39 \\
10 & 10,4 & 26 & 66,67 & 13 & 33,33 & 39 \\
11 & 11,4 & 31 & 79,49 & 8 & 20,51 & 39 \\
12 & 12,4 & 32 & 82,05 & 7 & 17,95 & 39 \\
13 & 13,4 & 32 & 82,05 & 7 & 17,95 & 39 \\
14 & 14,4 & 24 & 61,54 & 15 & 38,46 & 39 \\
15 & 15,4 & 26 & 66,67 & 13 & 33,33 & 39,90 \\
16 & 16,4 & 25 & 64,10 & 14 & & 39 \\
\hline
\end{tabular}

Selanjutnya di bawah ini akan diwajibkan data hasil belajar siswa pada SD Negeri No. 38/IX Jambi Kecil dalam mata pelajara IPS, data ini diperoleh dari daftar leger nilai hasil belajar Tahun pelajaran 2003/2004 Semester I. Adapun data yang dimaksud disajikan pada tabel berikut ini:

Tabel 2. Hasil Belajar

\begin{tabular}{ccc}
\hline No & Responden & Nilai \\
\hline 1 & 1,4 & 8,5 \\
2 & 2,4 & 7,5 \\
3 & 3,4 & 8 \\
4 & 4,4 & 7,3 \\
5 & 5,4 & 7,5 \\
6 & 6,4 & 7 \\
7 & 7,4 & 8 \\
8 & 8,4 & 6,6 \\
9 & 9,4 & 6,7 \\
10 & 10,4 & 6,9
\end{tabular}




\begin{tabular}{|c|c|c|}
\hline 11 & 11,4 & 6,7 \\
\hline 12 & 12,4 & 6,8 \\
\hline 13 & 13,4 & 6,7 \\
\hline 14 & 14,4 & 6,8 \\
\hline 15 & 15,4 & 7,8 \\
\hline 16 & 16,4 & 6,6 \\
\hline 17 & 17,4 & 6,5 \\
\hline 18 & 18,4 & 6 \\
\hline 19 & 19,5 & 8,5 \\
\hline 20 & 20,5 & 7,8 \\
\hline 21 & 21,5 & 8,6 \\
\hline 22 & 22,5 & 6,8 \\
\hline 23 & 23,5 & 7,7 \\
\hline 24 & 24,5 & 6,8 \\
\hline 25 & 25,5 & 6,7 \\
\hline 26 & 26,5 & 6,8 \\
\hline 27 & 27,5 & 7,8 \\
\hline-52 & 52,6 & 6,5 \\
\hline Jumlah Rata-Rata & & \\
\hline
\end{tabular}

\section{Klasifikasi Minat Membaca}

Setelah dipaparkan diskripsi data dan hasil penelitian sebagaimana yang terdapat pada tabel 6 diatas, maka untuk selanjutnya akan disajikan data klasifikasi minat membaca siswa SD Negeri No. 38/IX Jambi Kecil dalam mata pelajaran IPS, sebagaimana yang tertera pada tabel di bawah ini :

Tabel 3. Klasiikasi Minat Membaca

\begin{tabular}{|c|c|c|}
\hline No & Responden & Tingkat \% \\
\hline 1 & 1,4 & 87,18 \\
\hline 2 & 2,4 & 84,62 \\
\hline 3 & 3,4 & 82,05 \\
\hline 4 & 4,4 & 69,23 \\
\hline 5 & 5,4 & 66,77 \\
\hline 6 & 6,4 & 71,79 \\
\hline 7 & $7,4^{\mathrm{I}}$ & 92,31 \\
\hline 8 & 8,4 & 69,23 \\
\hline 9 & 9,4 & 53,85 \\
\hline 10 & 10,4 & 66,67 \\
\hline 11 & 11,4 & 79,49 \\
\hline 12 & 12,4 & 82,05 \\
\hline 13 & 13,4 & 82,05 \\
\hline 14 & 14,4 & 61,54 \\
\hline 15 & 15,4 & 66,67 \\
\hline 16 & 16,4 & 64,10 \\
\hline 17 & 17,4 & 53,85 \\
\hline 18 & 18,4 & 56,41 \\
\hline 19 & 19,5 & 71,79 \\
\hline 20 & 20,5 & 82,05 \\
\hline 21 & 21,5 & 92,31 \\
\hline 22 & 22,5 & 76,92 \\
\hline 23 & 23,5 & 94,87 \\
\hline 24 & 24,5 & 76,92 \\
\hline 25 & 25,5 & 79,49 \\
\hline 26 & 26,5 & 71,79 \\
\hline 27 & 27,5 & 61,54 \\
\hline 28 & 28,5 & 66,67 \\
\hline 29 & 29,5 & 69,23 \\
\hline 30 & 30,5 & 61,54 \\
\hline 31 & 31,5 & 61,54 \\
\hline 32 & 32,5 & 66,67 \\
\hline 33 & 33,5 & 66,67 \\
\hline 34 & 34,5 & 64,10 \\
\hline
\end{tabular}




$\begin{array}{rrr}35 & 35,5 & 69,23 \\ 36 & 36,6 & 53,85 \\ 37 & 37,6 & 82,05 \\ 38 & 38,6 & 82,05 \\ 39 & 39,6 & 84,61 \\ 40 & 40,6 & 92,31 \\ 41 & 41,6 & 89,74 \\ 42 & 42,6 & 82,05 \\ 43 & 43,6 & 71,79 \\ 44 & 44,6 & 76,92 \\ 45 & 45,6 & 58,97 \\ 46 & 46,6 & 64,10 \\ 47 & 47,6 & 61,54 \\ 48 & 48,6 & 66,67 \\ 49 & 49,6 & 64,10 \\ 50 & 50,6 & 71,79 \\ 51 & 51,6 & 66,67 \\ 52 & 52,6 & 61,54 \\ & \text { Jumlah : Rata }- \text { Rata } & 72,15 \%\end{array}$

Melihat hasil pegolahan data pada tabel diatas tersikap bahwa minat membaca siswa SD. Negeri No. 38/IX Jambi Kecil ternyata berada pada tingkat kualitas baik. Hasil ini diperoleh dari rata-rata jawaban responden pada tingkat persentase $72,15 \%$ dari siswa ini berarti siswa SD Negeri No. 38/IX Jambi Kecil memi iki minat untuk belajar membaca buku pelajaran IPS. Dengan minat ini diharapkan siswa memiiiki hasil belajar yang baik juga sesuai dengan standar yang diterapkan.

\section{Klasifikasi Prestasi Belajar}

Hasil prestasi belajar siswa SD Negeri No. 38/IX Jambi Kecil pada semester I Tahun Ajaran : 2003/2004 dapat disajikan dalam tabel 10 dibawah ini :

Tabel 4. Klasifikasi Prestasi Belajar

\begin{tabular}{|c|c|c|}
\hline No & Responden & Nilai IPS \\
\hline 1 & 1,4 & 8.5 \\
\hline 2 & 2,4 & 7.5 \\
\hline 3 & 3,4 & 8.0 \\
\hline 4 & 4,4 & 7.3 \\
\hline 5 & 5,4 & 7.5 \\
\hline 6 & 6,4 & 7.0 \\
\hline 7 & 7,4 & 8.0 \\
\hline 8 & 8,4 & 6.6 \\
\hline 9 & 9,4 & 6.7 \\
\hline 10 & 10,4 & 6.9 \\
\hline 11 & 11,4 & 6.7 \\
\hline 12 & 12,4 & 6.8 \\
\hline 13 & 13,4 & 6.7 \\
\hline 14 & 14,4 & 6.8 \\
\hline 15 & 15,4 & 7.8 \\
\hline 16 & 16,4 & 6.6 \\
\hline 17 & 17,4 & 6.0 \\
\hline 18 & 18,4 & 8.5 \\
\hline 19 & 19,5 & 7.8 \\
\hline 20 & 20,5 & 8.6 \\
\hline 21 & 21,5 & 6,8 \\
\hline 22 & 22,5 & 7.7 \\
\hline 23 & 23,5 & 6.8 \\
\hline 24 & 24,5 & 6.7 \\
\hline 25 & 25,5 & 6.8 \\
\hline 26 & 26,5 & 7.8 \\
\hline 27 & 27,5 & 6.8 \\
\hline 28 & 28,5 & 6.8 \\
\hline
\end{tabular}




$\begin{array}{lrr}29 & 29,5 & 8.5 \\ 30 & 30,5 & 6.8 \\ 31 & 31,5 & 6.8 \\ 32 & 32,5 & 6.8 \\ 33 & 33,5 & 6.8 \\ 34 & 34,5 & 6.7 \\ 35 & 35,5 & 6.8 \\ 36 & 36,6 & 6.0 \\ 37 & 37,6 & 7.3 \\ 38 & 38,6 & 7.5 \\ 39 & 39,6 & 8.5 \\ 40 & 40,6 & 8.4 \\ 41 & 41,6 & 7.5 \\ 42 & 42,6 & 7.4 \\ 43 & 43,6 & 7.5 \\ 44 & 44,6 & 6.8 \\ 45 & 45,6 & 6.0 \\ 46 & 46,6 & 6.7 \\ 47 & 47,6 & 7.5 \\ 48 & 48,6 & 6.7 \\ 49 & 49,6 & 7.8 \\ 50 & 50,6 & 7.5 \\ 51 & 51,6 & 6.7 \\ & 52,6 & 6.5 \\ & & 719\end{array}$

Berdasarkan hasil pengolahan data prestasi belajar siswa SD Negeri No: 30/1X Jambi Kecil, sebagaimana dalam tabel 9 diatas menunjukkan bahwa rata-rata prestasi belajar siswa tersebut adalah 7,19 hal ini dapat diketahui bahwa prestas belajar siswa berada pada tingkat di atas standar keluiusan atau ketuntasan standar kelulusan, siswa sudah dianggap berhasil dalam menguasai materi pelajaran adalah nilai di atas 6,0. dengan demikian berarti siswa SD Negeri No. 38/IX Jambi Kecil memiliki prestasi belajar yang baik dalam mata pelajaran IPS.

\section{Korelasi Minat Membaca dengan Prestasi Belajar}

Hasil pengolahan data penelitian untuk melihat tingkat bagaimana hubungan (korelasi) antara minat membaca dengan prestasi belajar Siswa SD Negeri No. 38/IX Jambi Kecil untuk mata pelajaran IPS. Sebelum mencari korelasi terlebih dahulu hash mengungkapkan daa tentang minat membaca dijadikan data mentah dengan cara tingkat persentase yang telah diperoleh sebagaimana dalam tabel di atas. Selanjutnya di bagi 10, angka 10 diambil dari nilai maksimal (tertinggi) prestasi belajar. Hasil pengolahan datanyadapat dilihat pada table dibawah:

Tabel 5. Nilai Rata-Rata Minat Membaca

\begin{tabular}{cccccc}
\hline No & Kode Responden & Tingkat Persentase Persentase & Bagi 10 & Hasil & Pembulatan \\
\hline 1 & 1,4 & 87.18 & $87.18: 10$ & 8.718 & 8.7 \\
2 & 2,4 & 84.62 & $84.62: 10$ & 8.462 & 8.5 \\
3 & 3,4 & 82.05 & $82.05: 10$ & 8.205 & 8.2 \\
4 & 4,4 & 69.23 & $69.23: 10$ & 6.923 & 6.9 \\
5 & 5,4 & 66.67 & $66.67: 10$ & 6.667 & 6.7 \\
6 & 6,4 & 71.79 & $71.79: 10$ & 7.179 & 7.2 \\
7 & 7,4 & 92.31 & $92.31: 10$ & 9.231 & 9.2 \\
8 & 8,4 & 69.23 & $69.23: 10$ & 6.923 & 6.9 \\
9 & 9,4 & 53.85 & $53.85: 10$ & 5.385 & 5.4 \\
10 & 10,4 & 66.67 & $66.67: 10$ & 6.667 & 6.7 \\
11 & 11,4 & 79.49 & $79.49: 10$ & 7.949 & 7.9 \\
12 & 12,4 & 82.05 & $82.05: 10$ & 8.205 & 8.2 \\
13 & 13,4 & 61.54 & $82.05: 10$ & 8.205 & 8.2 \\
14 & 14,4 & 61.54 & $61.54: 10$ & 6.154 & 6.1 \\
15 & 15,4 & 66.67 & $66.67: 10$ & 6.667 & 6.7 \\
16 & 16,4 & 64.10 & $64.10: 10$ & 6.410 & 6.4
\end{tabular}




$\begin{array}{cccccc}17 & 17,4 & 53.85 & 53.85: 10 & 5.385 & 5.4 \\ 18 & 18,4 & 56.41 & 56.41: 10 & 5.641 & 5.6 \\ 19 & 19,5 & 71.79 & 71.79: 10 & 7.179 & 7.2 \\ 20 & 20,5 & 82.05 & 82.05: 10 & 8.205 & 8.2 \\ 21 & 21,5 & 92.31 & 92.31: 10 & 9.231 & 9.2 \\ 22 & 22,5 & 76.92 & 76.92: 10 & 7.629 & 7.7 \\ 23 & 23,5 & 94.87 & 94.87: 10 & 9.487 & 9.5 \\ 24 & 24,5 & 76.92 & 76.92: 10 & 7.692 & 7.7 \\ 25 & 25,5 & 79.49 & 79.49: 10 & 7.949 & 7.9 \\ 26 & 26,5 & 71.79 & 71.79: 10 & 7.179 & 7.2 \\ 27 & 27,5 & 61.54 & 61.54: 10 & 6.154 & 6.1 \\ 28 & 28.5 & 66.67 & 66.67: 10 & 6.667 & 6.7 \\ 29 & 29.5 & 69.23 & 69.23: 10 & 6.923 & 6.9 \\ 30 & 30.5 & 61.54 & 61.54: 10 & 6.154 & 6.1 \\ 31 & 31.5 & 61.54 & 61.54: 10 & 6.154 & 6.1 \\ 32 & 32.5 & 66.67 & 66.67: 10 & 6.667 & 6.7 \\ 33 & 33.5 & 66.67 & 66.67: 10 & 6.667 & 6.7 \\ 34 & 34.5 & 64.1 & 64.10: 10 & 6.410 & 6.4 \\ 35 & 35.5 & 69.23 & 69.23: 10 & 6.923 & 6.9 \\ 37 & 36.6 & 53.85 & 53.85: 10 & 5.385 & 5.4 \\ \end{array}$

Sudah diperoleh nilai rata-rata dari minat membaca siswa SD Negeri No. 38/IX Jambi Kecil sebagaimana dalam tabel di atas selanjutnya akan diuraikan hasil penelitian untuk melihat korelasi minat membaca dengan prestasi belajar siswa SD Negeri No 38/IX Jambi Kecil. Untuk melihat korelasinya digunakan pengolahan data dengan tekhnik produk momen adapun hasil penelitian terdapat dalam tabel di dawah:

Tabel 6. Korelasi Minat membaca dengan prestasi belajar

\begin{tabular}{|c|c|c|c|c|c|c|}
\hline No & Responden & Minat (x) & Rapor (y) & $(\mathrm{x}) 2$ & (y) 2 & (xy) \\
\hline 1 & 2 & 3 & 4 & 5 & 6 & 7 \\
\hline 1 & 1,4 & 8.7 & 8.5 & 75.69 & 72.25 & 73.95 \\
\hline 2 & 2,4 & 8.5 & 7.5 & 72.25 & 56.25 & 63.75 \\
\hline 3 & 3,4 & 8.2 & 8.0 & 67.24 & 64.00 & 65.60 \\
\hline 4 & 4,4 & 6.9 & 7.3 & 47.61 & 53.29 & 50.37 \\
\hline 5 & 5,4 & 6.7 & 7.5 & 44.89 & 56.25 & 50.25 \\
\hline 6 & 6,4 & 7.2 & 7.0 & 51.84 & 49.00 & 50.40 \\
\hline 7 & 7,4 & 9.2 & 8.0 & 84.64 & 64.00 & 73.60 \\
\hline 8 & 8,4 & 6.9 & 6.6 & 47.61 & 43.56 & 45.54 \\
\hline 9 & 9,4 & 5.4 & 6.7 & 29.16 & 44.89 & 36.18 \\
\hline 10 & 10,4 & 6.7 & 6.9 & 44.89 & 44.61 & 46.23 \\
\hline 11 & 11,4 & 7.9 & 6.7 & 62.41 & 44.89 & 52.93 \\
\hline 12 & 12,4 & 8.2 & 6.8 & 6724 & 46.24 & 55.76 \\
\hline 13 & 13,4 & 8.2 & 6.7 & 67.24 & 44.89 & 54.94 \\
\hline 14 & 14,4 & 6.1 & 6.8 & 3721 & 46.24 & 41.48 \\
\hline 15 & 15,4 & 6.7 & 7.8 & 44.89 & 60.84 & 52.26 \\
\hline 16 & 16,4 & 6.4 & 6.6 & 40.96 & 43.56 & 42.24 \\
\hline 17 & 17,4 & 5.4 & 6.5 & 29.16 & 42.25 & 35.10 \\
\hline 18 & 78,4 & 5.6 & 6.0 & 31.36 & 36.00 & 33.60 \\
\hline 19 & 19,5 & 7.2 & 8.5 & 51.84 & 72.25 & 61.20 \\
\hline 20 & 20,5 & 8.2 & 7.8 & 67.28 & 60.84 & 63.96 \\
\hline 21 & 21,5 & 9.2 & 8.6 & 84.64 & 73.96 & 79.12 \\
\hline 22 & 22,5 & 7.7 & 6.8 & 59.29 & 46.24 & 52.36 \\
\hline 23 & 23,5 & 9.5 & 7.7 & 90.25 & 59.29 & 73.15 \\
\hline 24 & 24,5 & 7.7 & 6.8 & 59.29 & 4624 & 52.36 \\
\hline 25 & 25,5 & 7.9 & 6.7 & 62.41 & 44.89 & 52.93 \\
\hline 26 & 26,5 & 7.2 & 6.8 & 51.84 & 46.24 & 48.96 \\
\hline 27 & 27,5 & 6.1 & 7.8 & 37.21 & 60.84 & 47.58 \\
\hline 28 & 28.5 & 6.7 & 6.8 & 44.89 & 46.24 & 45.56 \\
\hline 29 & 29.5 & 6.9 & 8.5 & 47.61 & 72.25 & 58.65 \\
\hline
\end{tabular}




\begin{tabular}{lrrrrrr}
\hline 30 & & & & & \\
31 & 30.5 & 6.1 & 6.8 & 37.21 & 4624 & 41.48 \\
32 & 31.5 & 6.7 & 6.8 & 37.21 & 46.24 & 41.48 \\
33 & 32.5 & 6.7 & 6.8 & 44.89 & 44.89 & 44.89 \\
34 & 33.5 & 6.7 & 6.8 & 44.89 & 46.24 & 45.56 \\
35 & 34.5 & 6.4 & 6.7 & 40.96 & 44.89 & 42.88 \\
36 & 35.5 & 6.9 & 6.8 & 47.61 & 46.24 & 46.92 \\
37 & 36.6 & 5.4 & 6.0 & 29.16 & 36.00 & 32.40 \\
38 & 37.6 & 8.2 & 7.3 & 67.24 & 53.29 & 59.86 \\
39 & 38.6 & 8.2 & 7.5 & 67.24 & 56.25 & 61.50 \\
40 & 39.6 & 8.5 & 8.5 & 72.25 & 7225 & 72.25 \\
41 & 40.6 & 9.2 & 8.4 & 84.64 & 70.56 & 77.28 \\
42 & 41.6 & 9 & 7.5 & 81.00 & 56.25 & 67.50 \\
43 & 42.6 & 8.2 & 7.4 & 67.24 & 54.76 & 60.68 \\
44 & 43.6 & 7.2 & 7.5 & 51.84 & 5625 & 54.00 \\
45 & 44.6 & 7.7 & 6.8 & 59.29 & 46.24 & 52.36 \\
46 & 45.6 & 5.9 & 6.0 & 34.81 & 36.00 & 35.40 \\
47 & 46.6 & 6.4 & 6.7 & 40.96 & 44.89 & 42.88 \\
48 & 47.6 & 6.1 & 7.5 & 37.21 & 56.25 & 45.75 \\
49 & 48.6 & 6.7 & 6.7 & 44.89 & 44.89 & 44.89 \\
50 & 49.6 & 6.4 & 7.8 & 40.96 & 60.84 & I 49.92 \\
51 & 50.6 & 7.2 & 7.5 & 51.84 & 56.25 & 54.00 \\
52 & 51.6 & 6.7 & 6.7 & 44.89 & 44.89 & 14.89 \\
Jum1ah & 52.6 & 6.1 & 6.5 & 37.21 & 42.25 & 39.65 \\
\hline
\end{tabular}

Dengan demikian dapat disimpulkan bahwa terdapat hubungan yang positif antara minat membaca buku-buku IPS di SD Negeri No: 38/IX Jambi Kecil.

\section{Pembahasan \\ Klasifikasi Minat Membaca Siswa}

Berdasarkan hasil penelitian terungkap bahwa sebagian besar minat membaca siswa adalah berada pada tingkat baik. Hal ini dapat dilihat dari rata-rata jawaban responden pada tingkat presentase yaitu $72,15 \%$, dan hasil tersebut berarti siswa SD Negeri No. 38/IX Jambi Kecil, memiliki minat untuk belajar membaca buku-buku pelajaran IPS dengan minat membaca yang baik diharapkan agar siswa memiliki hasil belajar yang baik pula sesuai dengan yang diharapkan.

Secara garis besar membaca bertujuan untuk kesenangan, meningkatkan pengetahuan, dan untuk melakukan sesuatu. Maksudnya adalah dari kegiatan membaca banyak sekali manfaat yang dapat diperoleh oleh siswa. Siswa yang gemar membaca tidak hanya akan memperolah kesenangan akan tetapi dapat menambah informasi yang diperoleh dari bacaan yang dibacanya.

\section{Klafikasi Prestasi Belajar Siswa di SD Negeri No. 38/IX Jambi Kecil}

Berdasarkan hasil penelitian terungkap bahwa sebagian besar siswa (dominan) berada pada klasifikasi baik yaitu mempunyai rentang nilai 6,0-8,6 dari 52 responden terungkap bahwa rata-rata prestasi belajar siswa adalah 7,19 berada pada klasifikasi baik. Hasil ini dapat diketahui bahwa prestasi belajar siswa berada pada

Tingkat diatas standar kelulusan atau ketentuan standar kelulusan siswa dianggap berhasil diatas nilai 6,0 untuk mata pelajaran IPS. Dengan demikian terungkap bahwa siswa SD Negeri No. 38/IX Jambi Kecil memiliki prestasi belajar yang baik dalam mata pelajaran IPS. Secara presentase bila diukur dari tingkat kelulusan maka tidak ada lagi siswa yang belum mampu mencapai tingkat kelulusan. Semua siswa yang menjadi sampel penelitian dianggap telah mampu mencapai tingkat kelulusan khusus mata pelajaran IPS. Melihat dari hasil tingkat kelulusan, hanya sebagian kecil siswa yang mencapai batas pengayaan. Maksudnya adalah semua siswa yang berada pada klasifikasi prestasi belajar baik tidak ada yang perlu diberikan program pengayaan. Demikian pula halnya dengan siswa pengayaan. Demikian pula halnya dengan siswa yang berada pada klasifikasi prestasi belajar baik hanya sebagian yang patut mendapatkan program pengayaan. 


\section{Hubungan Minat Membaca Dengan Prestasi Belajar.}

Berdasarkan hasil penelitian bahwa hubungan minat membaca terhadap buku-buku IPS terhadap prestasi belajar dalam mata pelajaran IPS di SD Negeri No. 38/IX Jambi Kecil adalah sedang. Hal ini membuktikan bahwa hubungan minat membaca buku-buku IPS dengan prestasi belajar siswa di SD Negeri No. 38/IX Jambi Kecil dalam kondisi memadai. Dengan demikian dapat diambil kesimpulan bahwa siswa SD Negeri No. 38/IX Jambi Kecil memiliki minat membaca yang tinggi dan mempengaruhi hasil belajarnya dalam mata pelajaran IPS. Memadainya hubungan minat membaca buku-buku IPS tehadap prestasi belajar siswa dalam mata pelajaran IPS menunjukkan bahwa prestasi belajar siswa di sekolah di pengaruhi oleh tingkat kegemaran membaca siswa. Maksudnya adalah bila siswa banyak membaca maka banyak sekali informasi yang dapat diserap siswa. Informasi itu dapat berupa ilmu pengetahuan maupun petunjuk bagi suatu pengerjaan. Siswa yang gemar membaca akan memiliki keluasan pengetahuan dan pengalaman sehingga siswa memiliki kecendrungan yang lebih baik untuk sukses dalam belajar.

Selain itu, aktivitas membaca dengan belajar merupakan suatu aktivitas yang sulit untuk dibedakan. Maksudnya adalah hampir tidak ada aktivitas belajar yang tidak membutuhkan aktivitas membaca. Demikian juga dengan membaca adalah suatu aktivitas yang bertujuan untuk memperoleh informasi dari bacaan yang identik dengan beiajar itu sendiri. Siswa yang memiliki kegemaran membaca yang tinggi maka ia akan merasakan hubungan positif berupa manfaat sumbangan dari aktivitas membaca tersebut yang sangat besar terhadap prestasi belajarnya di sekolah.

\section{SIMPULAN}

Berdasarkan hasil penelitian terungkap bahwa hubungan minat mernbaca buku-buku IPS terhadap prestasi belajar dalam mata pelajaran IPS adalah sedang yaitu 0,638. Secara terperinci, juga dapat ditarik kesimpulan tentang klasifikasi minat membaca buku-buku IPS dengan prestasi belajar dalam mata pelajaran IPS di SD Negeri No. 38IlX Jambi Kecil sebagai berikut: Klasifikasi minat membaca buku-buku IPS siswa adalah berada pada rata-rata $72,15 \%$. Dari data ini dapat diambil kesimpulan bahwa klasifikasi minat membaca yang paling dominan adalah berada pada tingkat tinggi. Klasifikasi prestasi belajar siswa adalah dalam mata pelajaran IPS berada pada rata-rata 7,19. Dari data ini dapat diambil kesirnpulan bahwa klasifikasi prestasi belajar siswa yang paling dominan adalah berada pada tingkat tinggi. Hubungan minat membaca buku-buku IPS terhadap prestasi belajar siswa dalam mata pelajaran IPS adalah sedang yaitu 0,638. artinya adalah korelasi sedang hubungan memadai. Hal ini menunjukan bahwa ada hubungan yang memadai antara minat membaca buku-buku 1PS dengan prestasi belajar siswa dalam mata pelajaran IPS di SD Negeri No. 38/IX Jambi Kecil.

\section{DATAR PUSTAKA}

Abdurrahman, M. 1999, Pendidikan Anak Berkesulitan Belajar, PT. Rineka Cipta, Jakarta.

Abror, A. 1987. Psikologi Pendidikan. Tiara Wacana Yogya, Yogyakarta.

Afri, dkk. 1999, Layanan Bimbingan Belajar-Diktat. Fakultas Keguruan dan Ilmu Pendidikan Universitas Jambi. Jambi.

Arikunto, S., 1990, Manajemen Penelitian. PT. Reneka Cipta Jakarta

Dimyati, Mudjiono. 1994, Belajar dan Pembelajaran. Depdikbud, Dirjen Dikti. Proyek Pembinaan Tenaga Pendidik.

Nasution, N. 1995, Psikologi Pendidikan. Modul 1-6 Universitas Terbuka, Jakarta.

Purwanto, N. 1990. Psikologi Umum. PT. Rineka Cipta Jakarta.

Sardiman, 2000. Interaksi \& Motivasi Belajar Mengajar. PT. Raja Grafindo Persada, Jakarta.

Sukardi, D.K. 1995, Proses Bimbingan dan Penyuluhan. PT. Rineka Cipta Jakarta.

Surya, M. Rochman, N, 1995. Pengantar Bimbingan dan Penyuluhan. Modul 1-6 Universitas Terbuka Jakarta.

Suryabrata, S. 1994. Psikologi Pendidikan. CV. Rajawali, Jakarta.

Sutja, A. dkk. 2000. Panduan Penulisan Skripsi. Program Eksisitensi Bimbingan dan Konseling, FKIP, Universitas Jambi. Jambi.

Syah, M. 1997. Psikologi Pendidikan Dengan Pendekatan Baru. PT. Remaja Rosda Karya Bandung. 1997. Pengembangan Minat Membaca Buletin. PT. Balai Pustaka, Jakarta. 